\title{
Ten-Fold Decline in Mysis diluviana in Lake Champlain between 1975 and 2012
}

\author{
Suzanne C. Ball ${ }^{\mathrm{a}}$, Timothy B. Mihuc ${ }^{\mathrm{b}}$, Luke W. Myers ${ }^{\mathrm{b}}$, and Jason D. Stockwell ${ }^{\mathrm{a},{ }^{,}}$
}

${ }^{a}$ University of Vermont, Rubenstein Ecosystem Science Laboratory, 3 College Street, Burlington, Vermont 05401. Phone: 802.859.3095

${ }^{\mathrm{b}}$ Lake Champlain Research Institute, SUNY Plattsburgh, 101 Broad Street, Plattsburgh, NY 12901. Phone: 518.564.3039

*Corresponding author: jason.stockwell@uvm.edu

Email Addresses: suzanneball801@gmail.com (S.C. Ball), mihuctb@plattsburg.edu (T.B. Mihuc), myerslw@plattsburgh.edu (L.W. Myers)

Running Title: Decline in Lake Champlain Mysis diluviana 


\begin{abstract}
Mysis diluviana is an important mid-trophic level omnivore in many lakes, but studies of Mysis in Lake Champlain are rare. We used an unpublished 1975 study as a baseline to test for changes in contemporary Mysis populations in Lake Champlain. Invasive zebra mussels (Dreissena polymorpha) and alewives (Alosa pseudoharengus) were first reported in Lake Champlain in 1993 and 2003, respectively. Based on the negative relationships of these two species with Mysis and Mysis prey in the Great Lakes, we hypothesized a decline in Mysis in Lake Champlain since 1975 and tested this by repeating the 1975 study in 2012 . We found a nearly ten-fold decrease in mean density $( \pm$ SD) between $1975\left(712 \pm 373\right.$ individuals $\left./ \mathrm{m}^{2}\right)$ and $2012\left(82 \pm 48\right.$ individuals $/ \mathrm{m}^{2} ; \mathrm{p}=$ 0.002). Despite the decline, Mysis growth rates appeared similar between the two studies, although fecundity significantly increased by 3 embryos/female in $2012(\mathrm{p}=0.002)$. Mysis vertical distribution appeared similar in both years, while the horizontal distribution appeared limited to deeper bathymetric strata in 2012 compared to 1975. Data from a long-term monitoring program from 1992 to 2008 indicate the decline occurred abruptly in the mid-1990s, which coincided with zebra mussel establishment although a direct link between the two is not evident. Alewife did not invade Lake Champlain until 2003 and can be ruled out as a contributing factor to the decline. We hypothesize that the combination of predation by alewife and smelt and shifts in the planktonic food web may prevent Mysis from recovering to pre-1995 densities.
\end{abstract}

Keywords: Mysis, demographics, density, invasive species 


\section{Introduction}

Mysis diluviana (hereafter Mysis) is a mid-trophic level omnivore that undergoes diel vertical migration (DVM; Beeton and Bowers, 1982). Mysis consume detritus and benthic invertebrates during the day and migrate up to the metalimnion to feed on zooplankton and phytoplankton at night (Bowers and Grossnickle, 1978; Lasenby and Langford, 1973; Parker, 1980). In the Laurentian Great Lakes, Mysis are an important prey item for many fishes, including alewife (Alosa pseudoharengus), rainbow smelt (Osmerus mordax), deepwater sculpin (Myoxocephalus thompsoni), Coregonus spp., and siscowet lake trout (Salvelinus namaycush siscowet) (Gamble et al., 2011a, 2011b; Mills et al., 1992; Pothoven et al., 2004). Due to their feeding habits, DVM behavior, and importance as a prey item, Mysis can have large effects on upper and lower food web dynamics (Gal et al., 2006; Martinez and Bergersen, 1991; Spencer et al., 1991).

Mysis, similar to other aquatic species, may be susceptible to impacts of invasive species. In the past two centuries, many exotic species have invaded the Laurentian Great Lakes, including alewife and Dreissena spp., causing or coinciding with large food web and nutrient changes. For example, alewives were first found in Lake Ontario in the 1860s and spread to all of the remaining Great Lakes by 1955 (Smith, 1970). Alewives feed on and compete with Mysis, and thus can cause both direct and indirect effects on Mysis (Janssen and Brandt, 1980; Lasenby and Langford, 1973; Mills et al., 1992). Zebra mussels (Dreissena polymorpha) were first found in Lake St. Clair in 1986 (Hebert et al., 1991), and from there invaded all the Great Lakes, resulting in increased water clarity, declines in chlorophyll $a$ concentration, sequestration of energy and phosphorous from pelagic to benthic zones, and changes in algal species, possibly increasing noxious algae 
blooms (Budd et al., 2001; Madenjian, 1995; Malkin et al., 2008; Stewart et al., 2010). Dreissena spp. have no apparent direct effect on Mysis, but have altered phytoplankton and zooplankton community composition, affecting Mysis food resources and lake trophic dynamics (Dermott and Kerec, 1997; Johannsson et al., 2011; Nalepa et al., 2000).

Although Lake Champlain does not have as many invasive species as the Great Lakes (Marsden and Hauser, 2009), its food web structure has been altered over the past two decades. Zebra mussels were first discovered in 1993 and pelagic veligers were distributed lake-wide by 1996 (Marsden et al., 2013). During this time, the zooplankton community underwent a major composition shift as rotifers in offshore waters precipitously declined between 1993 and 1997 (Mihuc et al., 2012). Alewives were first discovered in 2003, were present in the main lake by 2005 (Marsden and Hauser, 2009), and have been implicated in a shift to smaller zooplankton body sizes (Mihuc et al., 2012). Given the apparent negative relationships between invasive species and Mysis in other systems (Gal et al., 2006; Johannsson et al., 2011; Pothoven et al., 2004), we hypothesized that Mysis populations in Lake Champlain had declined over the past two decades. We tested this hypothesis by repeating a demographic study from 1975 (Gutowski, 1978) in 2012 and analyzing mysid data from the New York State Department of Environmental Conservation long-term monitoring program initiated in 1992, just prior to the discovery of zebra mussels, to 2008, after the establishment of alewives.

\section{Methods}




\section{5 and 2012 Sample Collections}

Gutowski (1978) sampled Mysis bi-weekly at a 100-m deep reference site in Lake

Champlain from April 17 to October 29, 1975. We followed his methodology as closely as possible to facilitate direct comparisons of Mysis demographics from 1975 and 2012. We note where methods differed.

In 2012, samples were collected approximately every two weeks from April 30 to November 14 between the hours of 10:00 and 16:00 at the same 100-m deep station sampled by Gutowski (1978; 442 27.56’ N 073 ${ }^{\circ} 17.57^{\prime}$ W; Fig. 1). Starting June 20, 2012, a temporary mooring was used to hold position at the reference station for the duration of the tows and removed at the end of the day.

On each sampling day, five vertical hauls were taken from the entire water column using a 0.5-m diameter standard plankton net with 250- $\mu \mathrm{m}$ mesh; Gutowski (1978) used a $280-\mu \mathrm{m}$ mesh. The entire net was lowered to the bottom of the lake, allowed to rest for 30 seconds to enable mysids to become redistributed, and retrieved at an average speed of $0.5 \mathrm{~m} / \mathrm{sec}$. Contents from each tow were emptied into dissecting trays for sorting. Preservation in formalin can cause the rupture of brood pouches, so all gravid females were isolated from the catch and preserved individually in 1.5-mL centrifuge tubes. The remainder of each sample was then emptied into a $250-\mathrm{mL}$ jar and preserved in $10 \%$ formalin. All samples were transferred to $70 \%$ ethyl alcohol within 24 hours. Secchi depth was also recorded on each sampling day.

Daytime vertical distribution of Mysis was measured in September 1975 and October 2012 at Site A (Fig. 1) using the plankton net. On October 26, 2012, vertical tows were taken from 95-m depth to surface, then every 5-m towards the surface until no mysids 
were captured. In 2012, when no Mysis were captured from a given depth, a second tow was taken. If Mysis were caught in the second tow, sampling continued to the next stratum. If no Mysis were caught in the second tow, sampling was finished. The density estimate from one tow was subtracted from the density estimate of the tow below it (e.g., 75-m catch minus 70-m catch) to obtain the number of Mysis for each 5-m stratum. The density estimate from the $95-\mathrm{m}$ tow was subtracted from the average of the 5 tows of the entire water column described above to estimate the density in the bottom 5-m layer. Mysis were stored in the $10 \%$ formalin solution and transferred to $70 \%$ ethyl alcohol in the laboratory within 24 hours.

To assess the extent of Mysis horizontal distribution as a function of lake depth, samples were collected twice in 2012 - on August 2 and November 14. Gutowski (1978) measured horizontal distribution on October 8, 1975. Three replicate samples were collected at each 10-m bathymetric contour starting at the 100-m reference station heading east towards Burlington, Vermont (Fig. 1). Sampling stopped at the first contour where no Mysis were captured in all replicates.

\section{5 and 2012 Sample Processing and Data Analyses}

In 2012, total length (TL; tip of the rostrum to the end of the telson, excluding setae) was measured to the nearest 0.1-mm using an Olympus SZX9 dissecting microscope and Image-Pro Insight software. Gutowski (1978) measured TL to the nearest mm (e.g., lengths of 5.0 to 5.9 were categorized as $5 \mathrm{~mm}$ ). Sexual maturity categories assigned to Mysis followed the protocols of Gutowski (1978); Mysis were grouped into juvenile, immature male, mature male, immature female, and mature female (Reynolds and 
DeGraeve, 1972). For each fecund female, the eggs and embryos were counted to make a regression of brood size to TL in 2012.

Density (individuals $/ \mathrm{m}^{2}$ ) for each tow was estimated by dividing the number of mysids caught by the area of the plankton net $\left(0.196 \mathrm{~m}^{2}\right)$. Mean density for the entire water column on each sampling date was estimated by averaging the five replicate tows, assuming $100 \%$ net efficiency. We considered the mean density on each sampling date (based on 5 replicates per date) as our sampling unit. To test for a difference in density between the years 1975 and 2012, we averaged density estimates within each month each year and then conducted a paired $t$-test $(\alpha=0.05)$.

Percent length-frequency distributions (LFDs) were created for each date to identify cohorts and track growth in each year. Gutowski (1978), based on his 1975 data presented here, proposed that Lake Champlain Mysis consisted of a winter cohort and a summer cohort. The winter cohort, released in February-March, would give rise to a summer cohort in 15-16 months (i.e., June-July of the following year), and the summer cohort would give rise to a winter cohort in 18-20 months (i.e., February-March in two calendar years). We used this framework to visually identify cohorts entering the population during 1975 and 2012, and used the constraint of observed autumn LFDs to estimate the trajectories of cohort growth in each year. To estimate growth rates in 1975, we averaged the three largest length bins for each cohort on each date as an indicator of the "advancing" edge of the cohort. We then regressed the mean length of each cohort's advancing edge against sampling date (Julian day) to estimate cohort growth rate in $\mathrm{mm} /$ day. For 2012, the relatively low number of available Mysis precluded consistent catches of cohorts, causing unreliable estimates of each cohort's advancing edge across 
sampling dates. Consequently, we used mean length of the advancing edge for each cohort from common start (late April for winter cohort and June-July for summer cohort) and end (late October) sampling dates to compare growth rates across the two years: (Mean TL $L_{\text {End }}-$ Mean TL $\left.L_{S t a r t}\right) /\left(J u l i a n\right.$ DayEnd $\left.-J_{\text {Julian Daystart }}\right)$.

Mysis sexual maturity categories were compared graphically between 1975 and 2012 to determine if percent composition had changed. Brood size of fecund females was also compared between the two years. Average brood size for each TL bin in 1975 was interpolated from Figure 6 in Gutowski (1978). We then averaged 2012 brood sizes within the same TL bins (i.e., $14 \mathrm{~mm}=14.0$ to $14.9 \mathrm{~mm}, 15 \mathrm{~mm}=15.0$ to $15.9 \mathrm{~mm}$, etc.). We compared fecundity between the two years by using an ANOVA model with year as a nominal factor and TL as a continuous variable, and tested for a significant interaction to indicate a difference in slope. Because no difference was found, we then used ANCOVA to test for a difference in intercepts using the same model without an interaction term. Both tests were run using R (CRAN-Project) with $\alpha=0.05$. For 2012 data, we excluded potential outliers (females with only one embryo or fecund females not separated from the rest of the sample, possibly allowing brood pouch rupture).

In the present study, Mysis used to develop a length-mass regression were measured for TL as described above, blotted with a paper towel, and then weighed on a Mettler Toledo AX204 scale to the nearest $0.1 \mathrm{mg}$. After being measured and sexed, the Mysis were preserved again in $70 \%$ ethanol for a total of two weeks to ensure all were preserved for the same amount of time. After two weeks, individuals were measured for length again, blotted and weighed to the nearest $0.1 \mathrm{mg}$, dried at $60^{\circ} \mathrm{C}$ for $>24$ hours, and weighed again. We generated a length-mass regression from a subset of our 2012 wet 
mass samples and then applied it to length-frequency data to estimate biomass to compare with Gutowski's (1978) biomass estimates from 1975. We also compared our length-mass regression to that reported by Gutowski (1978). Individual length-mass data were not included in Gutowski (1978), making it difficult to directly compare data. Length and wet mass were linearized using ln-transformation, and the slope and intercept were estimated with linear regression. A length-dry mass regression was produced to compare 2012 Lake Champlain Mysis with published relationships in other systems. Because Gutowski (1978) only reported a length-wet mass regression, and did not include any of the data points that generated the relationship, direct comparisons of length-mass relationships between the two years was not possible. In lieu of this, we applied the 1975 length-mass relationship to lengths from 2012 and compared predicted mass with those predicted from the 2012 length-mass regression.

\section{2-2008 Monitoring Protocols}

Each year from 1992 to 2008, between 11 and 54 Mysis samples were collected between June 15 and September 15 during daylight hours from three sites in the main lake (except in 1992 when Site C was not sampled; Fig. 1). Each sampling day at each sampled station, three vertical tows were taken from the entire water column using paired bongo nets (0.5-m diameter, $253-\mu \mathrm{m}$ mesh). During each tow, the nets were lowered to

just above the sediment, and allowed to rest for approximately 30 seconds before retrieving at approximately $1 \mathrm{~m} / \mathrm{sec}$. Samples were washed into $125 \mathrm{ml}$ bottles and stored in buffered 5\% formalin-sucrose solution on ice to be transported to the laboratory for further processing. Mysis were then stored in $95 \%$ ethyl alcohol until further processing. 
All Mysis were counted, classified as juvenile, male, or female, and TL measured to the nearest $1 \mathrm{~mm}$. The mean density ( $\pm \mathrm{SD}$ ) of Mysis was calculated for each year to evaluate trends in Mysis. We used changepoint analysis (Hinkley, 1970) to test if and when Mysis density estimates changed over the 17-year period. Changepoint analysis was conducted using "cpt.mean" function in the R package "changepoint" (Killick and Eckley, 2014; CRAN-Project).

\section{Results}

1975 and 2012

Mean density ( \pm SD) of Mysis in $2012\left(82 \pm 48\right.$ individuals $\left./ \mathrm{m}^{2}\right)$ was significantly lower than in $1975\left(712 \pm 373\right.$ individuals $/ \mathrm{m}^{2} ; t=5.0, p=0.002$; Fig. 2a). The peak density of Mysis was 1,673 individuals $/ \mathrm{m}^{2}$ in July of 1975 and 208 individuals $/ \mathrm{m}^{2}$ in August of 2012 (Fig. 2a). Biomass followed a similar trend in both years (Fig. 2b). The average biomass of Mysis in 1975 was 6.5 wet $\mathrm{g} / \mathrm{m}^{2}$ and ranged from 2.4 to 12.9 wet $\mathrm{g} / \mathrm{m}^{2}$. In 2012 , the average was 1.2 wet $\mathrm{g} / \mathrm{m}^{2}$, ranging from 0.04 to 2.6 wet $\mathrm{g} / \mathrm{m}^{2}$.

Mysis were found in each depth stratum from 70 to $100 \mathrm{~m}$ during the day in September 1975 and October 2012 (Fig. 3). Juveniles were more abundant than adults over the entire water column in both years. In 1975, immature males and females were the most abundant group in the $95-100 \mathrm{~m}$ strata. Juveniles and mature individuals became more abundant in waters shallower than $90 \mathrm{~m}$.

In 2012, Mysis were not found along the sampling transect at bottom depths shallower than $80 \mathrm{~m}$ in August and $70 \mathrm{~m}$ in November. In 1975, Mysis were found at bottom depths as shallow as $50 \mathrm{~m}$ in October (Fig. 4). Mean secchi depths ( \pm SD) were $4.1 \pm 0.87 \mathrm{~m}$ in 
$1975(\mathrm{n}=14$; Gutowski 1978) and $4.4 \pm 1.2 \mathrm{~m}$ in $2012(\mathrm{n}=15)$, and were not significantly different $(\mathrm{t}=0.79, \mathrm{df}=27, \mathrm{p}=0.43)$.

A cohort indicative of winter brood release was evident in April in each of 1975 and 2012 (Fig. 5). Although recruitment appears continuous from May into June 1975, a large influx of new recruits ( $3 \mathrm{~mm}$ ) on July 7 suggests a summer cohort (Fig. 5; Gutowski 1978). In 2012, a summer cohort appeared on June 20. Growth rates of the winter and summer 1975 cohorts, based on the change in the mean TL of the advancing edge of each cohort, were estimated at 0.051 and $0.047 \mathrm{~mm} /$ day (Fig. 6). The difficulty in tracking individual cohorts across all sampling dates in 2012 (e.g., the older summer cohort is represented by only one length bin on June 20; Fig. 5) constrained us to use the mean TL of the advancing edge of cohorts at the start and end of the sampling season (Fig. 6) to estimate growth rates. We estimated growth rate of the 2012 winter and summer cohorts at 0.056 and $0.043 \mathrm{~mm} /$ day. Using the same method, we estimated growth rate of the 1975 winter and summer cohorts at 0.052 and $0.048 \mathrm{~mm} /$ day.

No notable differences were apparent between length-wet mass relationships between 1975 and 2012 (Fig. 7a), but this is a qualitative assessment because raw data were not available from 1975. Any possible difference in the length-mass relationship between the two years in Lake Champlain (Fig. 7a) appears small compared to cross-system differences among other North American lakes (Morgan, 1985; Fig. 7b).

The number of embryos per female increased with TL (Fig. 8). We found no significant difference in slopes between the two years $(F=1.45, p=0.25)$, but we did find a significant difference in intercept (year effect, $\mathrm{F}=15.4, \mathrm{p}=0.002$; TL effect, $\mathrm{F}=$ 209.3, $\mathrm{p}<0.001 ; \mathrm{n}=16$, adjusted $\left.\mathrm{R}^{2}=0.94, \mathrm{DF}=13,2\right)$. The equations describing 
fecundity as a function of TL for each year are $1.96 * \mathrm{TL}+\mathrm{b}$ where $\mathrm{b}$ is -16.46 for 1975 and -13.68 for 2012 .

In addition to the significant difference in densities between 1975 and 2012 (Fig. 2a), there appeared to be a larger percentage of mature females in April/May 1975 compared to the same period in 2012, and a larger percentage of mature males in September and October 2012 compared to the same period in 1975 (Fig. 9). Juveniles made up a high percentage of the population in both years, with a steady decline into autumn in 1975 and an abrupt decline in August in 2012 (Fig. 9).

Long- Term Monitoring 1992 - 2008

The Lake Champlain Mysis population declined from 1992 to 2008 (Fig. 10). Changepoint analysis indicated a significant change in Mysis mean density between 1995 and 1996 (100\% confidence in changepoint estimate). Mysis mean density ( \pm SD) was $835 \pm 107$ individuals $/ \mathrm{m}^{2}$ from $1992-1995$ and $209 \pm 88$ individuals $/ \mathrm{m}^{2}$ from 1996-2008 (Fig. 10).

\section{Discussion}

Our results indicate that Lake Champlain Mysis demographics and distribution have changed between 1975 and 2012. Densities have declined nearly ten-fold since 1975; long-term monitoring shows that the decline occurred abruptly in the mid-1990s. In addition, the trajectories of the population composition in each year were very different. Mature females represented a large proportion of the population in spring 1975 whereas mature females represented a much smaller proportion of the population more consistently from spring into August 2012. Mature males were nearly absent in 1975 until 
October but were a relatively large proportion of the population in 2012 between August and September. In addition, the horizontal range of Mysis appears to have contracted between 1975 and 2012. Mysis were not captured shallower than the 70-m contour in 2012 whereas they were caught up to the 50-m contour in 1975 . The vertical distribution in both years consisted of individuals suspended off the bottom during the day, but a larger portion of the population was found near the bottom in 1975 compared to 2012. Both assessments of horizontal and vertical distributions were characterized by limited sampling in both years - one sampling date in 1975 and two in 2012 for the former and one date in each year for the latter. Therefore, our inferences of changes in Mysis distributions should be considered with some caution.

Despite the changes in densities, demographics, and distributions, we found no apparent differences in Mysis growth rates in 1975 versus 2012. The consistent growth rates suggest either (1) Mysis were not and still are not food limited, or (2) food has become more limiting concurrent with population decline. Copepod and cladoceran densities have remained steady since 1992 (Mihuc et al., 2012), suggesting no changes in mesozooplankton resources. Moreover, comparison of Mysis length-mass relationships in 1975 and 2012 with those from other North American lakes indicate any differences in growth rates within Lake Champlain in 1975 and 2012 are minimal compared to acrosssystem differences. Although Lake Champlain Mysis appear to have lower mass-at-length when compared to other systems, Lake Champlain was still able to support high Mysis densities prior to 1996. In fact, Lake Champlain Mysis densities in 1975 and prior to 1996 are among the highest recorded observations in the Great Lakes, similar to offshore estimates from Lake Ontario in the mid-1980s (Johannsson, 1992) and inshore estimates 
from Lake Michigan in the mid-1970s (Grossnickle and Morgan, 1979). We therefore conclude that the decline in Mysis populations was not a result of food limitation. For comparison, Mysis populations declined in Lake Ontario after the establishment of dreissenids, as did system-wide productivity (Johannsson et al., 2011). Growth rates, however, remained unchanged, suggesting mysids were able to compensate for decreased resources by feeding more efficiently compared to before the dreissenid invasion (Johannsson et al., 2011).

Although we found no change in growth rates in Lake Champlain, Mysis appear to have exhibited a density-dependent response in their fecundity. Individual fecund females had approximately three more embryos in 2012 compared to 1975. The lack of population recovery since the decline in the mid-1990s, however, suggests the increased fecundity is not sufficient to compensate for population losses.

The cause of the abrupt decline in Lake Champlain Mysis in the mid-1990s remains a mystery. No abrupt shifts in lake temperature or system productivity were apparent in the 1990s (Smeltzer et al., 2012). Zebra mussels appear to have caused major environmental and food web alterations in the Great Lakes (Budd et al., 2001; Dermott, 2001), and in Lake Champlain, a sharp reduction in rotifer populations coincident with the zebra mussel invasion through the mid-1990s suggests a direct link via filtration (Mihuc et al., 2012). Such shifts in the planktonic food web may have played a role in the Mysis declines, although densities of cladocera, preferred prey of Mysis (e.g., O’Malley and Bunnell 2014), did not show any striking changes during the mid-1990s when Mysis decreased (Mihuc et al., 2012). The concomitant decline of Mysis with rotifers suggests a 
connection, but factors in addition to zebra mussels, acting in concert with changes in rotifer populations, may also be responsible.

Disease and predation are two other hypotheses that could explain the abrupt decline in Mysis densities in Lake Champlain. Epizootics that severely reduce wild populations over short time scales are not uncommon (Bain et al. 2010; Traxler and Rankin 1989) and remain a viable hypothesis, although no recorded epizootic for Mysis spp. has been recorded (nor tested for). Populations can usually recover from epizootics, but Lake Champlain Mysis have not recovered. Invasive species can also negatively impact native species that have not evolved mechanisms to defend against a new predator or competitor (Mills et al., 1994). Alewife invaded Lake Champlain but their invasion took place about a decade after the Mysis decline, thus eliminating alewife as a cause of the decline. Alewife establishment in Lake Champlain, however, may now act as an obstacle for population recovery. The initial impact of an epizootic followed by continued suppression by invasive alewife via predation is a plausible hypothesis. However, any increase in Mysis predation by alewife may possibly be more than offset by decreases in rainbow smelt predation if alewife negatively influence rainbow smelt abundance (e.g., via predation or competition). Alewives do not appear to have negatively influenced rainbow smelt in the Great Lakes (Madenjian et al., 2008), and we have not seen a decrease in zooplankton resources since alewife were first found in Lake Champlain (Mihuc et al., 2012) that would suggest intense competition between the two planktivores. We thus hypothesize that alewife will increase the overall predation pressure on Mysis, reducing the probability for Mysis recovery. The 10-year period 
between the decline of Mysis (1995-1996) and the proliferation of alewife in the lake (2005), however, challenge the epizootic-increased predation pressure hypothesis.

A final hypothesis for consideration is predation impacts by native rainbow smelt (Osmerus mordax). The high inter-annual variability in smelt population densities are likely insufficient to keep consistent predation pressure on Mysis to cause a drastic decline (Kirn and LaBar, 1996; Thomson et al., 2011). Smelt densities were variable from 1990 to 2009, but higher peaks in CPUE were seen after 1996 in the Main Lake (Staats and Pientka, 2010), likely a consequence of a 50\% reduction in lake trout stocking after 1994 (Ellrott and Marsden, 2003). In addition, age structure of smelt shifted to younger ages between 1996 and 1999, presumably reducing smelt predation pressure on Mysis because younger smelt (age 0 and 1) eat less Mysis (Labar, 1993; Staats and Pientka, 2010; Thomson et al., 2011). Increased smelt populations could exert indirect pressure on Mysis through increased competition for zooplankton resources, but this would not explain the decline of Mysis, and cladoceran and copepod populations have remained at similar densities between 1992 and 2008 (Mihuc et al., 2012).

We sampled during the day using vertical plankton net tows, whereas conventional Mysis sampling occurs at night. We might expect lower densities a priori because Mysis undergo diel vertical migration and are more susceptible to plankton nets at night. Therefore, an alternative explanation for the lower Mysis densities we observed starting in 1996 is that Mysis underwent a strong distributional shift to the bottom at this time, which made Mysis virtually unavailable to our gear compared to 1975 (sensu McQuinn, 2009). Recent Mysis density estimates based on night acoustic sampling $(<75$ 
individuals $/ \mathrm{m}^{2}$; Hrycik et al., 2015), however, corroborate our low daytime density estimates, suggesting the observed decline in Lake Champlain Mysis is real.

Our replication of Gutowski's (1978) study and trends from the long-term monitoring program indicate Mysis population demographics in Lake Champlain have changed considerably between 1975 and 2012, with a major perturbation occurring abruptly in the mid-1990s. At this time, zebra mussels or other factors causing declines in rotifer populations, or an epizootic coupled with an invasive predator, are leading hypotheses for the decline and continued low population levels of Mysis. Testing these hypotheses and the ramifications of the decline in Mysis populations on Lake Champlain food web dynamics would provide valuable insight into the potential impacts of Mysis declines in the Great Lakes, where declines in the benthic macroinvertebrate Diporeia may shift fish predation increasingly to Mysis (Hondorp et al., 2005; Nalepa et al., 2000; Owens and Dittman, 2003, Owens and Weber, 1995). Moreover, our results suggest that Mysis populations can collapse regardless of Diporeia dynamics because Diporeia has not constituted a major part of the Lake Champlain food web (Hensen and Potash, 1970; Levey and Fiske, 1996). Such a collapse of Mysis in the Great Lakes could pose an ecological challenge for native species recovery (Zimmerman and Krueger, 2009) because most native species, at one or more life stages, rely on Mysis as a significant prey resource (Gamble et al., 2011a, 2011b; Isaac et al., 2012; Rand et al., 1995).

\section{Acknowledgements}

We would like to thank our colleagues at the Rubenstein Ecosystem Science Laboratory who assisted in sample collection and analysis, especially Chelsea Mitchell, Peter 
Euclide, and Mitchell Jones. We are grateful to the captain of the $R / V$ Melosira, Steve Cluett, and first mate Pat Gorman for their hard work and dedication to this project. Long-term mysid data is courtesy of the NYDEC and Lake Champlain Monitoring program, funded by the Lake Champlain Basin Program (USEPA). We thank Ellen Marsden and Peter Euclide for providing helpful comments on the manuscript. Support for this research was provided by Vermont EPSCoR with funds from the National Science Foundation Grant EPS-1101317 and a University of Vermont Office of Undergraduate Research Mini-Grant to SCB.

\section{References}

Bain, M.B., Cornwell, E.R., Hope, K.M., Eckerlin, G.E., Casey, R.N., Groocock, G.H., Getchell, R.G., Bowser, P.R., Winton, J.R., Batts, W.N., Cangelosi, A., Casey, J.W., 2010. Distribution of an invasive aquatic pathogen (Viral Hemorrhagic Septicemia Virus) in the Great Lakes and its relationship to shipping. PloS ONE 5, e10256.

Beeton, A.M., Bowers, J.A., 1982. Vertical migration of Mysis relicta Lovén. Hydrobiol. 93, 53-61.

Bowers, J.A., Grossnickle, N.E., 1978. The herbivorous habits of Mysis relicta in Lake Michigan. Am. Soc. Limnol. Oceanogr. 23, 767-776.

Budd, J.W., Drummer, T.D., Nalepa, T.F., Fahnenstiel, G.L., 2001. Remote sensing of biotic effects: zebra mussels (Dreissena polymorpha) influence on water clarity in Saginaw Bay, Lake Huron. Limnol. Oceanogr. 46, 213-223.

Dermott, R., Kerec, D., 1997. Changes to the deep-water benthos of eastern Lake Erie since the invasion of Dreissena: 1979-1993. Can. J. Fish. Aquat. Sci. 54, 922-930. 
Dermott, R., 2001. Sudden disappearance of the amphipod Diporeia from eastern Lake Ontario, 1993-1995. J. Great Lakes Res. 27, 423-433.

Ellrott, B. E., Marsden J. E. 2004. Lake trout restoration in Lake Champlain. Trans. Am. Fish. Soc. 133, 252-264.

Gal, G., Rudstam, L.G., Mills, E.L., Lantry, J.R., Johannsson, O.E., Greene, C.H., 2006. Mysid and fish zooplanktivory in Lake Ontario: quantification of direct and indirect effects. Can. J. Fish. Aquat. Sci. 63, 2734-2747.

Gamble, A.E., Hrabik, T.R., Stockwell, J.D., Yule, D.L., 2011a. Trophic connections in Lake Superior part I: the offshore fish community. J. Great Lakes Res. 37, 541-549.

Gamble, A.E., Hrabik, T.R., Yule, D.L., Stockwell, J.D., 2011b. Trophic connections in Lake Superior part II: the nearshore fish community. J. Great Lakes Res. 37, 550-560.

Grossnickle, N., Morgan, M., 1979. Density estimates of Mysis relicta in Lake Michigan. J. Fish. Res. Board Canada 36, 694-698.

Gutowski, T.B. 1978. The ecology of Mysis relicta (Lovén) in Lake Champlain. Master thesis, Department of Zoology, University of Vermont, Burlington, Vermont, USA.

Hebert, P.D.N, Wilson, C.C., Murdoch, M.H., Lazar, M.R., 1991. Demography and ecological impacts of the invading mollusc Dreissena polymorpha. Can. J. Zool. 69, 405-409.

Hensen, E.B., Potash, M., 1970. Limnology of Lake Champlain: 1965-1970. A Completion Report to the Office of Water Resources Research, Department of Interior. $25 \mathrm{pp}$.

Hinkley, D.V. 1970. Inference about the change-point in a sequence of random variables. Biometrika 57, 1-17. 
Hondorp, D.W., Pothoven, S.A., Brandt, S.B., 2005. Influence of Diporeia density on diet composition, relative abundance, and energy density of planktivorous fishes in southeast Lake Michigan. Trans. Am. Fish. Soc. 134, 588-601.

Hrycik, A.R., Simonin, P.W., Rudstam, L.G., Parrish, D.L., Pientka, B., Mihuc, T.B., In review. Importance of Mysis zooplanktivory in Lake Champlain: a bioenergetics analysis. J. Great Lakes Res. 41, this issue.

Isaac, E.J., Hrabik, T.R., Stockwell, J.D., Gamble, A.E., 2012. Prey selection by the Lake Superior fish community. J. Great Lakes Res. 38, 326-335.

Janssen, J., Brandt, S.B., 1980. Feeding ecology and vertical migration of adult alewives (Alosa pseudoharengus) in Lake Michigan. Can. J. Fish. Aquat. Sci. 37, 177-184.

Johannsson, O.E., 1992. Life history and productivity of Mysis relicta in Lake Ontario. J. Great Lakes Res. 18, 154-168.

Johannsson, O.E., 1995. Response of Mysis relicta population dynamics and productivity to spatial and seasonal gradients in Lake Ontario. Can. J. Fish. Aquat. Sci. 52, 154168.

Johannsson, O.E., Bowen, K.L., Holeck, K.T., Walsh, M.G., 2011. Mysis diluviana population and cohort dynamics in Lake Ontario before and after the establishment of Dreissena spp., Cercopagis pengoi, and Byhotrephes longimanus. Can. J. Fish. Aquat. Sci. 68, 795-811.

Killick, R., Eckley, I.A. 2014. changepoint: An R package for changepoint analysis. Journal of Statistical Software 58, 1-19.

Kirn, R.A., LaBar, G.W., 1996. Growth and survival of rainbow smelt, and their role as prey for stocked salmonids in Lake Champlain. Trans. Am. Fish. Soc. 125, 87-96. 
LaBar, G.W., 1993. Use of bioenergetics models to predict the effect of increased lake trout predation on rainbow smelt following sea lamprey control. Trans. Am. Fish. Soc. $122,942-950$.

Lasenby, D.C., Langford, R.R., 1972. Growth, life history, and respiration of Mysis relicta in and arctic temperate lake. J. Fish Res. Bd. Can. 29, 1701-1708.

Lasenby, D.C., Langford, R.R., 1973. Feeding and assimilation of Mysis relicta. Am. Soc. Limnol. Ocean. 18, 280-285.

Levey, R., Fiske, S., 1996. Survey of the shale and cobble zone macroinvertebrate community 1995. Vermont Department of Environmental Conservation. Report prepared for the Lake Champlain Basin Program and the U.S. Environmental Protection Agency, Regions 1 and 2. 41 pp.

Madenjian, C.P., 1995. Removal of algae by the zebra mussel (Dreissena polymorpha) population in western Lake Erie: a bioenergetics approach. Can. J. Fish. Aquat. Sci. $52,381-390$.

Madenjian, C.P., O’Gorman, R., Bunnell, D.B., Argyle, R.L., Roseman, E.F., Warner, D. M., Stockwell, J.D., Stapanian, M.A., 2008. Adverse effects of alewives on Great Lakes communities. N. Am. J. Fish. Manage. 28, 263-282.

Malkin, S.Y., Guildford, S.J., Hecky, R.E., 2008. Modeling the growth response of Cladophora in a Laurentian Great Lake to the exotic invader Dreissena and to lake warming. Limnol. Oceanogr. 53, 1111-1124.

Marsden, J.E., Hauser, M., 2009. Exotic species in Lake Champlain. J. Great Lakes Res. $35,250-265$. 
Marsden, J.E., Stangel, P., Shambaugh, A. 2013. Zebra mussels in Lake Champlain: a sixteen-year monitoring database. Chapter 2, In: T. Nalepa and D. Schloesser, Quagga and Zebra Mussels: Biology, Impacts, and Control, $2^{\text {nd }}$ ed. CRC Press.

Martinez, P.J., Bergersen, E.P., 1991. Interactions of zooplankton, Mysis relicta, and kokanees in Lake Granby, Colorado. Am. Fish. Soc. Symp. 9, 49-64.

McQuinn, I., 2009. Pelagic fish outburst or suprabenthic habitat occupation: legacy of the Atlantic cod (Gadus morhua) collapse in eastern Canada. Can. J. Fish. Aquat. Sci. 66, $2256-2262$

Mihuc, T.B., Dunlap, F., Binggeli, C., Myers, L., Pershyn, C., Groves, A., Waring, A., 2012. Long-term patterns in Lake Champlain's zooplankton: 1992-2010. J. Great Lakes Res. 38, 49-57.

Mills, E.L., Leach, J.H., Carlton, J.T., Secor, C.L., 1994. Exotic species and the integrity of the Great Lakes. BioSci. 44, 666-676.

Mills, E.L., O’Gorman, R., DeGisi, J., Heberger, R.F., House, R.A., 1992. Food of the alewife (Alosa pseudoharengus) in Lake Ontario before and after the establishment of Bythotrephes cederstroemi. Can. J. Fish. Aquat. Sci. 49, 2009-2019.

Morgan, M.D., 1979. The dynamics of and introduced population of Mysis relicta (Loven) in Emerald Bay and Lake Tahoe, California-Nevada. PhD thesis, Univ. California-Davis.

Morgan, M.D., 1985. Growth and its relationship to reproduction in Mysis relicta, in: Wenner, A. (Ed.), Factors in Adult Growth. A.A. Balkema Publishers, Netherlands, pp. 235-250. 
Nalepa, T.F., Hartson, D.J., Buchanan, J., Cavaletto, J.F., Lang, G.A., Lozano, S.J., 2000. Spatial variation in density, mean size and physiological condition of the holarctic amphipod Diporeia spp. in Lake Michigan. Freshw. Biol. 43, 107-119.

O’Malley, B.P., Bunnell, D.B., 2014. Diet of Mysis diluviana reveals seasonal patterns of omnivory and consumption of invasive species in offshore Lake Michigan. J. Plankton Res. 36, 989-1002.

Owens, R.W., Dittman, D.E., 2003. Shifts in the diets of slimy sculpin (Cottus cognatus) and lake whitefish (Coregonus clupeaformis) in Lake Ontario following the collapse of the burrowing amphipod Diporeia. Aquat. Ecosyst. Health Manag. 6, 311-323.

Owens, R.W., Weber, R.W., 1995. Predation on Mysis relicta by slimy sculpins (Cottus cognatus) in southern Lake Ontario. J. Great Lakes Res. 21, 275-283.

Parker, J.I., 1980. Predation by Mysis relicta on Pontoporeia hoyi: a food chain link of potential importance in the Great Lakes. J. Great Lakes Res. 6, 164-166.

Pothoven, S.A., Fahnenstiel, G.L., Vanderploeg, H.A., 2004. Spatial distribution, biomass, and population dynamics of Mysis relicta in Lake Michigan. Hydrobiol. 522, 291-299.

Rand, P.S., Stewart, D.J., Lantry, B.F., Rudstam, L.G., Johannsson, O.E., Goyke, A.P., Brandt, S.B., O'Gorman, R., Eck, G.W., 1995. Effect of lake-wide planktivory by the pelagic prey fish community in Lakes Michigan and Ontario. Can. J. Fish. Aquat. Sci. $52,1546-1563$.

Reynolds, J.G., DeGraeve, G.M., 1972. Seasonal population characteristics of the opossum shrimp, Mysis relicta, in southeastern Lake Michigan. Proc. $15^{\text {th }}$ Conf. Great Lakes Res. 117-131. 
Smeltzer, E., Shambaugh, A.D., Stangel, P., 2012. Environmental change in Lake Champlain revealed by long-term monitoring. J. Great Lakes Res. 38, 6-18.

Smith, S.H., 1970. Species interactions of the alewife in the Great Lakes. Trans. Am. Fish. Soc 99, 754-765.

Spencer, C.N., McClelland, B.R., Stanford, J.A., 1991. Shrimp stocking, salmon collapse, and eagle displacement. BioSci. 41, 14-21.

Staats, N.R., Pientka, B., 2010. Project No. F-35-R-12. Vermont Fish and Wildlife Department Annual Report. Essex, VT.

Stewart, T.J., Johannsson, O.E., Holeck, K., Sprules, W.G., O’Gorman, R., 2010. The Lake Ontario zooplankton community before (1987-1991) and after (2001-2005) invasion-induced ecosystem change. J. Great Lakes Res. 36, 596-605.

Thomson, J.L.S., Parrish, D.L., Parker-Stetter, S.L., Rudstam, L.G., Sullivan, P.J., 2011. Growth rates of rainbow smelt in Lake Champlain: effects of density and diet. Ecol. Freshw. Fish 20, 503-512.

Traxler, G.S., Rankin, J.B., 1989. An infectious hematopoietic necrosis epizootic in sockeye salmon Oncorhynchus nerka in Weaver creek spawning channel, Fraser River system, B.C., Canada. Dis. Aquat. Org. 6, 221-226.

Zimmerman, M.S., Krueger, C.C., 2009. An ecosystem perspective on reestablishing native deepwater fishes in the Laurentian Great Lakes. North Am. J. Fish. Manag. 29, $1352-1371$. 


\section{List of Figures}

Figure 1. Map of Lake Champlain, Vermont and New York, USA, and Quebec, Canada with 1975 and 2012 sampling sites (Site A; 100 m deep) and long-term monitoring sites (Sites A, Site B [122 m]), and C [97 m]).

Figure 2. (a) Mean $( \pm \mathrm{SD})$ density (individuals $/ \mathrm{m}^{2}$ ) of Mysis in 1975 and 2012 for all sampling dates (5 vertical tows/date) at the 100-m depth station in Lake Champlain.

(b) Comparison of biomass density (wet $\mathrm{g} / \mathrm{m}^{2}$ ) of Mysis as a function of sampling date in 1975 and 2012 in Lake Champlain.

Figure 3. Densities of Mysis at each vertical depth stratum at site A on 29 September 1975 and 26 October of 2012.

Figure 4. Horizontal distribution of Mysis eastward from Site $A$ in Lake Champlain on October 8, 1975, August 2, 2012, and November 14, 2012. Standard deviations calculated from each depth stratum are shown for 2012. No measure of variation is available for 1975 data.

Figure 5. Percent length-frequency distributions for paired sampling dates in 1975 and 2012. Cohorts are identified by horizontal bars at top of each panel (1975) and just above the $\mathrm{x}$-axis scale (2012). Solid portions of the horizontal bars indicate winter cohorts and open portions indicate summer cohorts.

Figure 6. Mean total length of the advancing edge of winter (circles) and summer (squares) cohorts in 1975 (open symbols) and 2012 (closed symbols). Lines represent linear regression for 1975 cohorts.

Figure 7. Mass (mg) as a function of total length (mm) of Mysis. (a) Comparison of 1975 and 2012 Mysis (wet mg) in Lake Champlain. Individual equations are $\mathrm{W}=$ 
$0.0206 \mathrm{~L}^{2.68}(2012)$ and $\mathrm{W}=0.0074 \mathrm{~L}^{3.00}(1975$; Gutowski 1978). (b) Comparison of Mysis (dry mg) among North American lakes including Lake Champlain in 2012 (W $=0.0015 \mathrm{~L}^{3.00}$; this study), Stoney Lake $\left(\mathrm{W}=0.00345 \mathrm{~L}^{2.84} ;\right.$ Lasenby and Langford, 1972), Lake Tahoe (W = 0.00152L $\mathrm{L}^{3.08}$; Morgan, 1979), and Emerald Bay (W = $0.00148 \mathrm{~L}^{3.03}$; Morgan, 1979).

Figure 8. Mean number of embryos per female Mysis in 1975 (Gutowski 1978) and 2012 in Lake Champlain.

Figure 9. Cumulative percent composition of Mysis life-stage categories for each sampling date in Lake Champlain in 1975 (left) and 2012 (right). The vertical width between lines represents the percentage that life-stage category contributes to the total samples collected.

Figure 10. Mean Mysis density estimates ( \pm SD) from 1992 to 2008 from daytime vertical tows at three reference sites in Lake Champlain, sampled in June, July, August, and September. Horizontal lines represent mean Mysis densities between 1992-1995 and 1996-2008. 


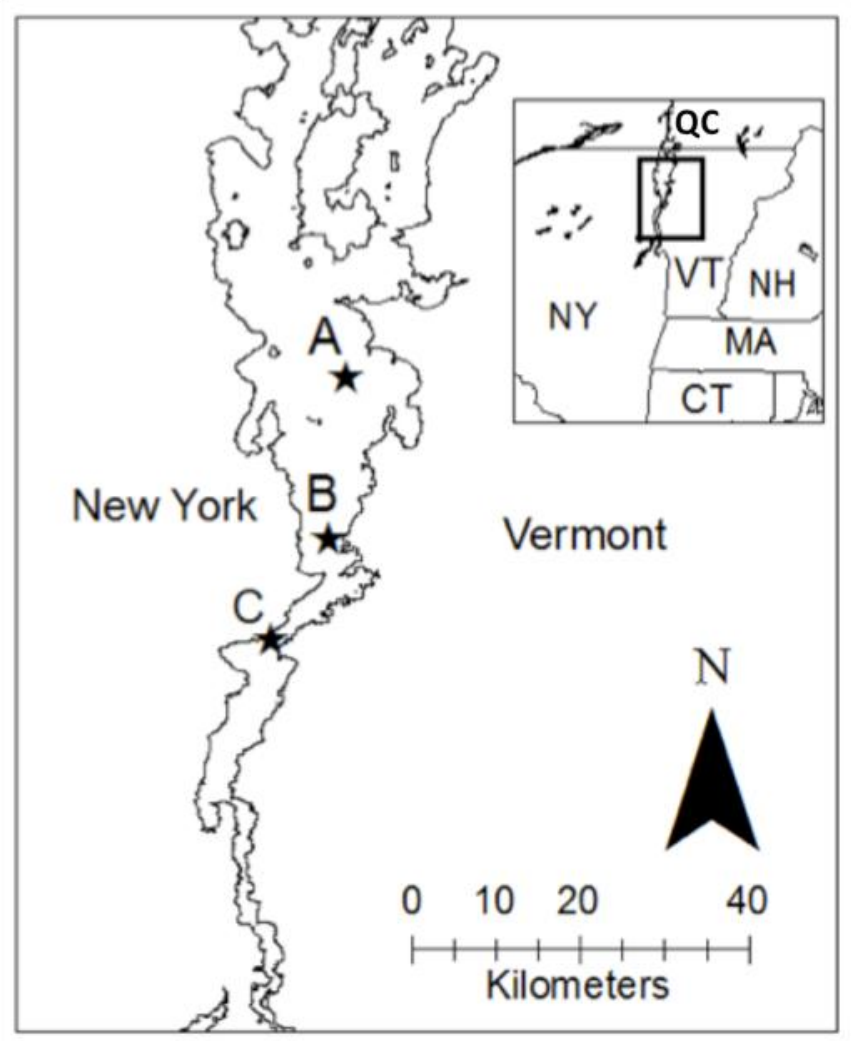

Figure 1 

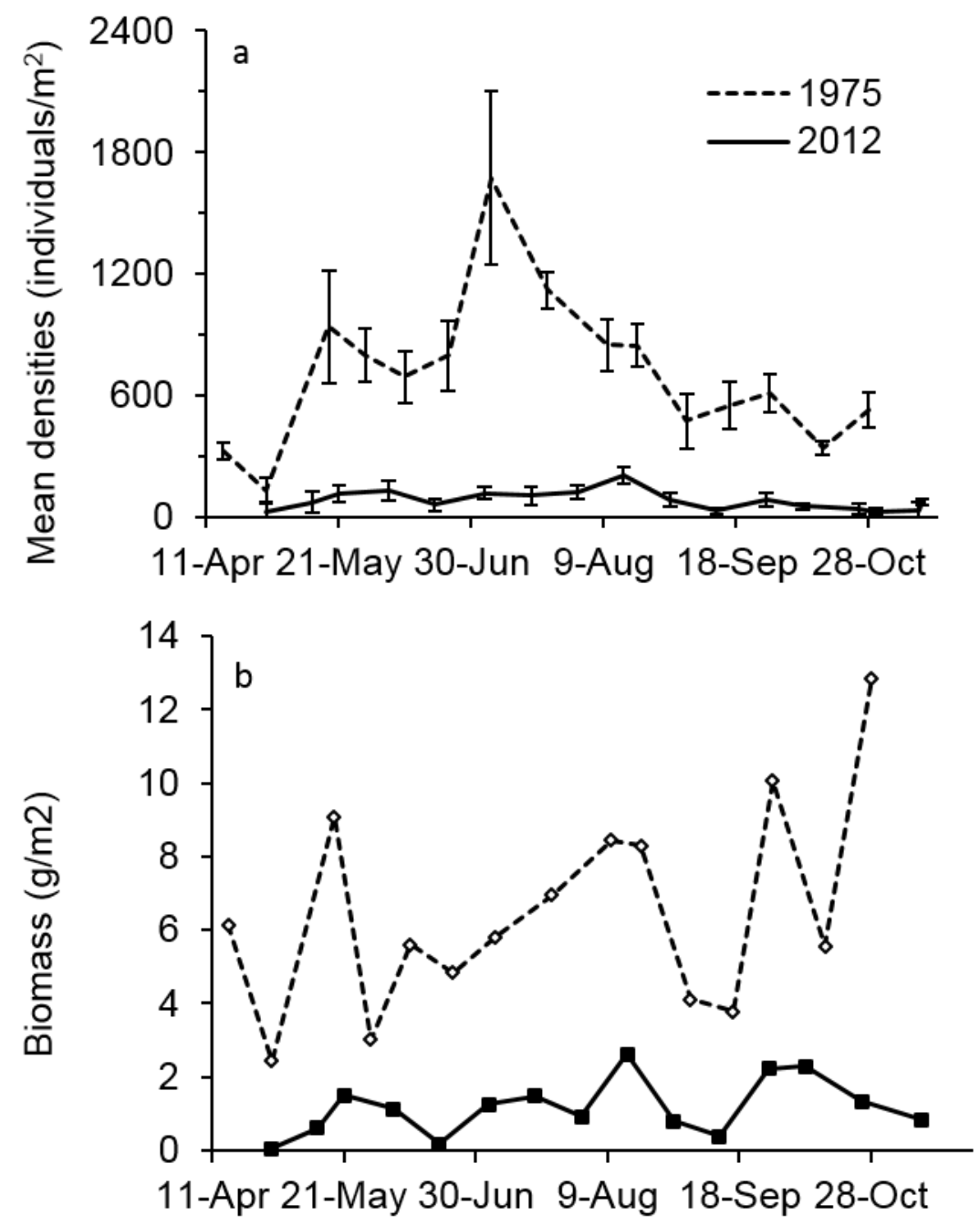

Figure 2 


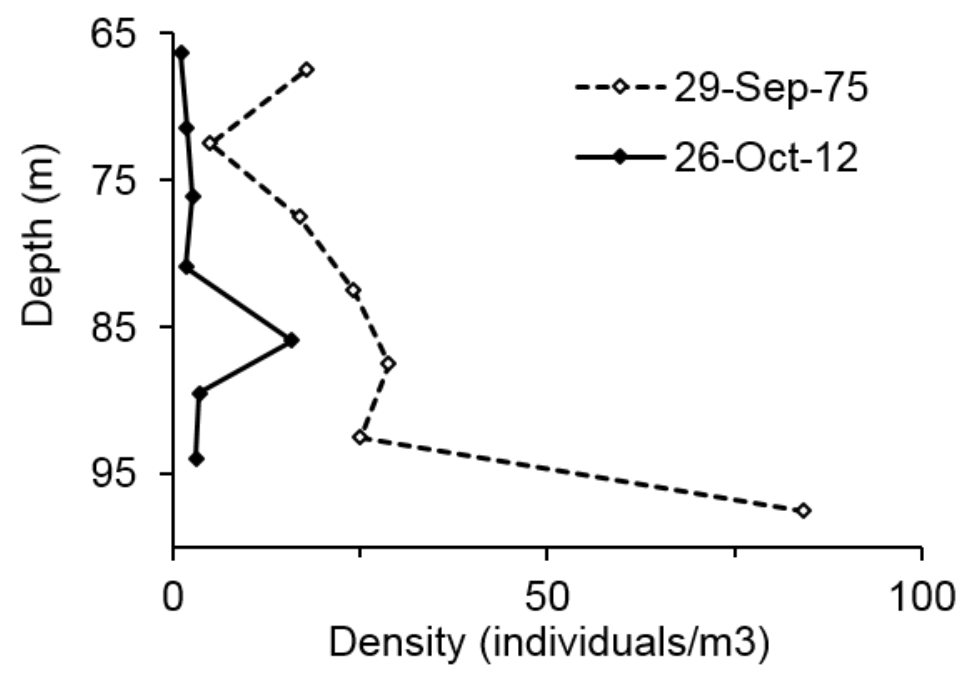

Figure 3 


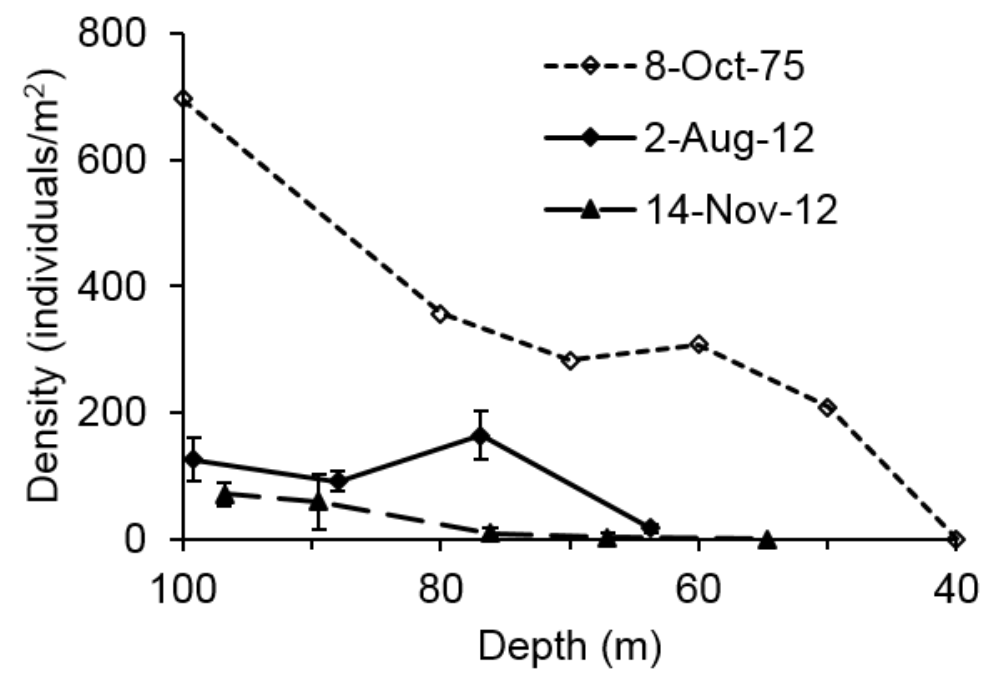

Figure 4 

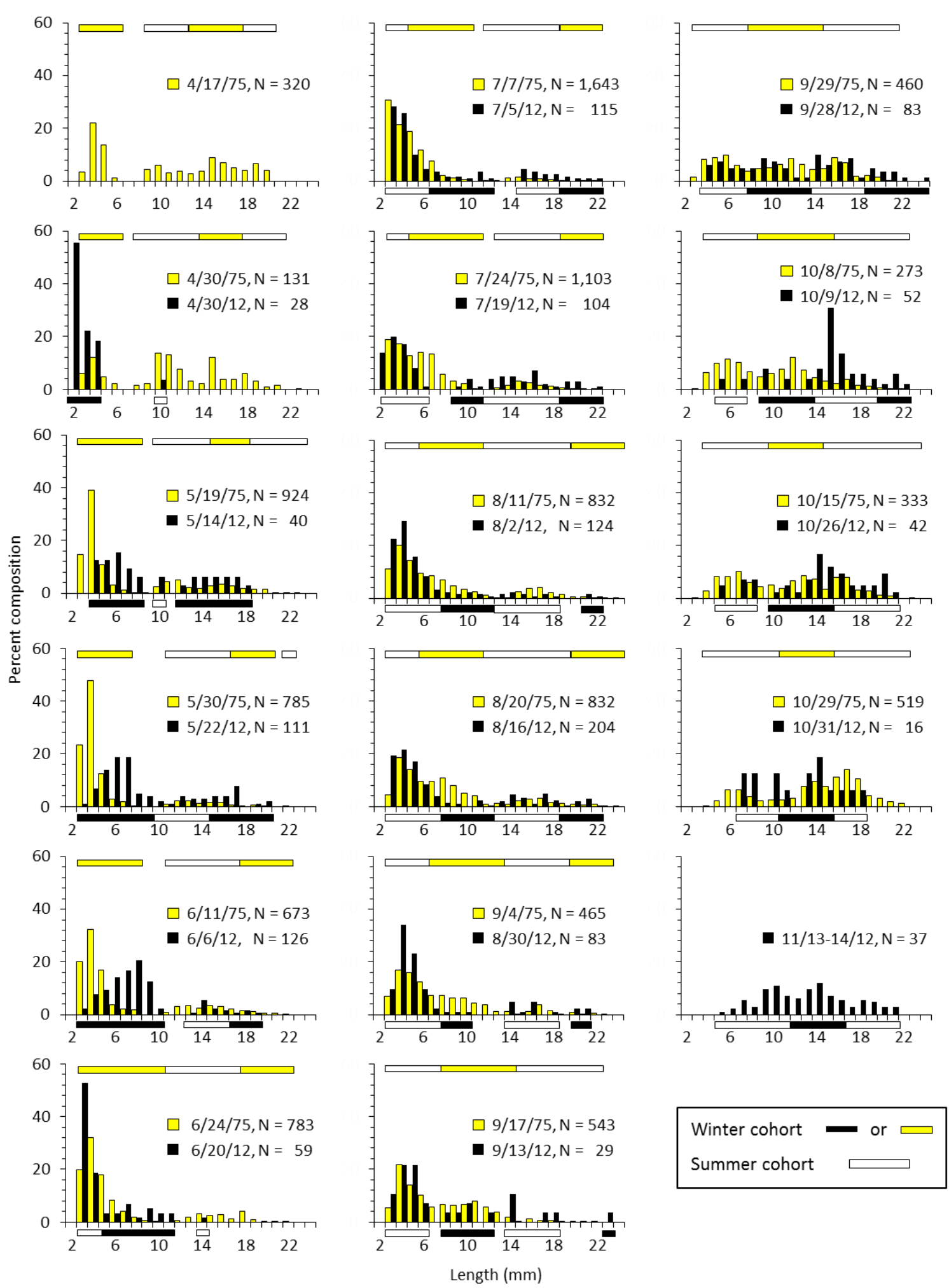

Figure 5 


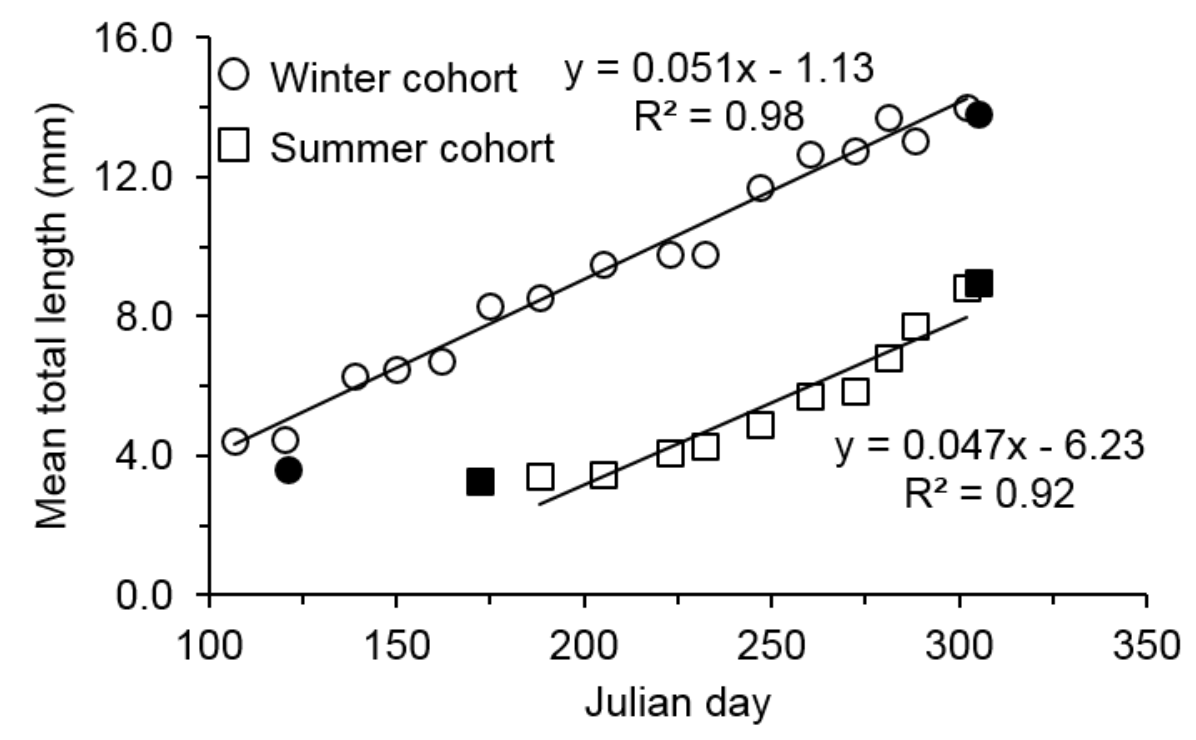

Figure 6 




Figure 7 


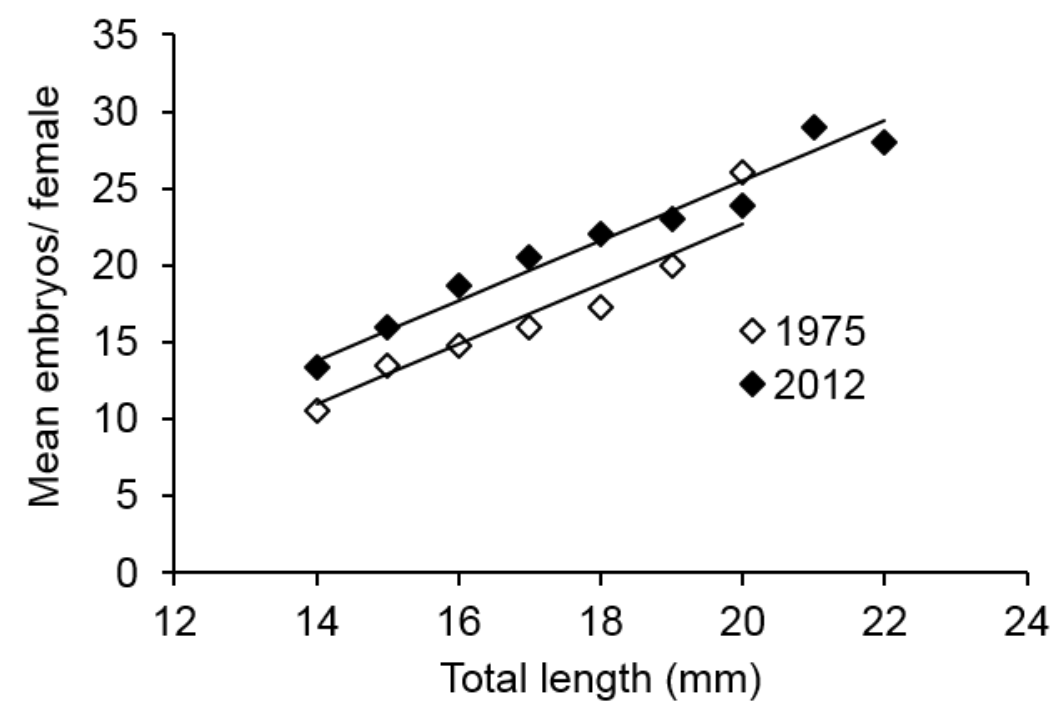

Figure 8 




Figure 9 


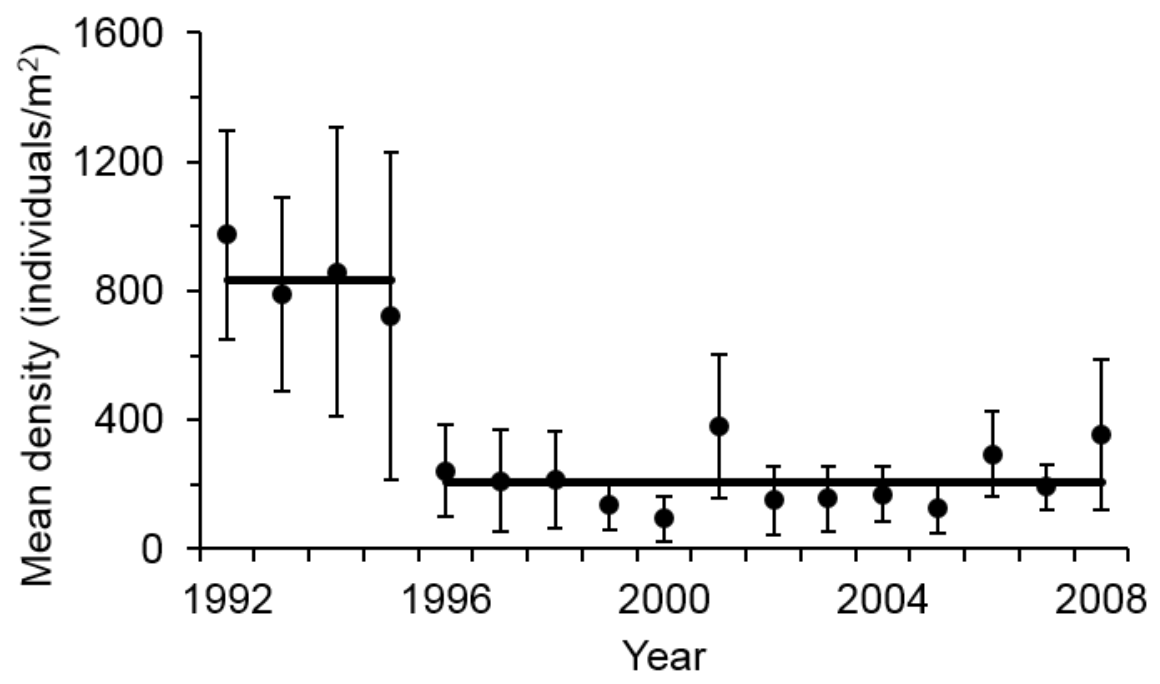

Figure 10 